\title{
ÚLTIMOS CUIDADOS DE ENFERMAGEM PRESTADOS AO PACIENTE(*)
}

\author{
Enf. Elza Helena Ribeiro Barretto (**)
}

"Prestar assistência ao indivíduo enfermo ou sadio no desempenho de atividades que contribuem para manter a saúde, ou para recuperá-la ou ter uma morte serena - atividades que ele desempenharia se tivesse força, vontade ou conhecimentos necessários", .são as funções que competem exclusivamente à enfermeira, conforme consta dos "Princípios básicos sobre cuidados de enfermagem", de Virgínia Henderson. E ela ainda continua: "Os cuidados de enfermagem a serem executados por enfermeiras qualificadas estão sendo, frequentemente, limitados apenas à supervisão de cuidados julgados complexos, que exigem alto grau de habilidade e capacidade de julgamento, ou aos que se devem aos pacientes enfermos".

É a respeito da supervisão de um importante cuidado de enfermagem, que exige paciência e amor, que desejamos nos referir o último cuidado devido ao paciente que não voltará ao seu lar, nem receberá nossas instruções e conselhos reservados para o dia da alta hospitalar, porque expirou serenamente...

Esse corpo, agora sem vida, merece o melhor dos nossos cuidados, o máximo da nossa atenção; não será pelo fato de ter expirado que deixará de ser nosso paciente. Os compendios e manuais de técnicas de enfermagem dedicam, em suas páginas finais, capítulos referentes ao assunto.

Talvez esse último cuidado de enfermagem seja um banho no leito uma limpeza da boca, dos lábios ou do nariz, um pentear de cabelos, um aparar de unhas, um corte de barba, ou uma troca de roupas.

* Apresenta 4. ${ }^{\text {a }}$ Jornada de Enfermagem do INPS - S. Paulo - 1973.

** ENF. Hospital Brigadeiro - INPS - S. Paulo. 
Após a alta hospitalar, como também após a vida, devemos entregar nosso paciente aos seus familiares, com aparência de conforto, de serenidade, esteticamente arrumado.

Entre flores, velas, perfumes e cores, como você gostaria de encontrar um rosto amigo?

Devemos àquele paciente uma última ajuda no sentido de bem se apesentar aos parentes e amigos que permanecerão junto dele por mais algumas horas.

E importante que ele se comunique com os que o cercam, através de um semblante tranquilo, durante aqueles momentos de repouso obrigatório e perene...

Tiny M. Calender, em seu livro "Administração Hospitalar para Enfermeiras" lembra que de uma administração deficiente resultará um serviço assistencial também deficiente.

Nas capelas mortuárias, nos velórios e morgeus públicos ou nos necrotérios de nossos hospitais, deparamos, às vezes, com um corpo mal preparado, principalmente com um rosto totalmente diferente daquele que conhecíamos.

A assistência de enfermagem deve abranger também o paciente sem vida, dedicando-lhe os últimos cuidados referentes à higiene, curativos e tamponamentos dos orifícios naturais.

Antes de deixar o leito hospitalar esse corpo deve receber a última visita da enfermeira para ver em que condições ele foi preparado.

E bom lembrarmos aqui, ou "fazermos de conta' que o necrotèrio é uma extensão do ambiente hospitalar, é um outro quarto ou uma outra enfermeira para onde foram transferidos, no silencio e do repouso eterno aqueles que foram nossos pacientes. E até lá, também deveria estender-se a atenção da enfermeira.

Quanto aos cuidados com os orifícios naturais, referência especial merecem os da cabeça, principalmente a boca e as fossas nasais. O excesso de algodão neles introduzidos desfigura as feições e impressiona mal. O tamponamento das cavidades naturais é o derraceiro cuidado de enfermagem dispensado ao paciente. Com muito respeito e paciência, o tamponamento deve ser feito nas primeiras horas após a constatação do óbito.

Impcrtante é dar a esse corpo, a esse rosto, um aspecto de naturalidade, de aparência normal. Chega-se a esse objetivo pela técnica do tamponamento orofaríngeo. Com esse cuidado, dispensam-se os excessos e a presença de algodão nas narinas ou nos lábios. A impressão causada ao se deparar, pela última vez, com um rosto mal apresentado ficará gravada por muito tempo na mente dos seus familiares. 
Nos casos de acidentados, queimados ou feridos na face, devemos procurar deixar livre a maior área possível do rosto do paciente, para que ele possa ser identificado e reconhecido. O serviço de enfermagem é o responsável por esses`cuidados complexos que também exigem alto grau de habilidade.

A estética faz parte da recuperação do corpo humano. Se a família o solicitasse (e já se tem visto), porque não se proceder a uma discreta maquilage de um rosto a isso acostumado, ou a um ligeiro retoque da pintura dos cabelos?

$\mathrm{Na}$ enfermagem, acompanhamos o ser humano, desde seu primeiro abrir de olhos, com oś cuidados ao recém-nascido, até o deslizar da última lágirima desses mesmos olhos que irão se fechar para sempre... Quanto contraste!

Fechar os olhos de alguém é missão nobre e triste, que também exige técnica (pois nem sempre há facilidade de eles se manterem fechados) com a costumeira pressão digital sobre as pálpebras. Algodão embebido em éter sobre elas, pur alguns minutos, ajudará para que se fechem.

Após os cuidados gerais, vejamos a técnica do tamponamento orofaríngeo:

- com uma pinça traciona-se a língua para a frente; com outra mais longa introduz-se algodão na região orofaríngea, o quanto necessário para bloquear também o rinofaringe.

- voltando a língua à sua posição normal fecha-se a boca justa-pondo-se os maxilares (se for o caso, colocar as dentaduras).

- uma faixa ou atadura manterá os maxilares unidos.

A má posição dos pés e das mãos também chamam a atenção das visitas e familiares Tanto os maxilares como os pés e as mãos não precisam ser atados com muita força, nem com várias voltas, nem com dois ou îres nós. A força, a volta e os nós em demasia. deformam a região comprida, dando-lhe aspecto desagradável.

Mostremos aos nossos colegas e funcionários (dos períodos diurno e noturno) e transmitamos aos nossos familiares e amigos a necessidade de se dispensar, aos que nos deixam, cuidados tão delicados e importantes.

Para nós, cristãos, o corpo humano é o templo vivo do Espírito Santo, é o abrigo da alma criada à imagem e semelhança de Deus. É justo portanto que, após o desenlace, receba toda veneração, carinho e ajuda, a fim de bem se apresentar aos que acompanham a aespedida. Dedique ao seu paciente, com amor, o último cuidado de enfermagem e ouça depois:

"Que expressão de serenidade!"

“Descansa em paz!”... 